\title{
Quantity Theory of Money: True or False
}

\author{
Chao Chiung Ting ${ }^{1}$ \\ ${ }^{1}$ Graduated from Michigan State University, USA \\ Correspondence: Chao Chiung Ting, Graduated from Michigan State University, $633398^{\text {th }}$ Place 1E, Rego Park, \\ NY 11374, USA. E-mail: tingtch7ti@aol.com
}

Received: July 31, 2017

Accepted: August 14, 2017

Online Published: September 5, 2017

doi:10.5539/ijef.v9n10p46

URL: https://doi.org/10.5539/ijef.v9n10p46

\begin{abstract}
I convert $F=m a$ into $m=F \div a$ arithmetically as economists convert $V=P Y \div M$ into $M V=P Y$. $m=F \div a$ predicts absurdly that there is no mass if acceleration is zero. For example, you do not have mass when you sleep. Similarly, $M V=P Y$ predicts ridiculously that there is no aggregate income if there is no money. In fact, barter economy operates. As force is scalar in $F=m a$ calculated as mass multiply acceleration so that force is not cause to determine mass in $m=F \div a$, income velocity is scalar in $V=P Y \div M$ calculated as ex-post nominal aggregate income is divided by ex-post quantity of money stock so that aggregate income does not depend on income velocity. Since the symbol $V$ in $V=P Y \div M$ is scalar and the symbol $V$ in $M V=P Y$ is cause so that $M V=P Y$ is not equivalent to $V=P Y \div M$, arithmetical conversion is an invalid method to prove $M V=P Y$. In other words, it is computation that $M V=P Y$ is equivalent to $V=P Y \div M$ as exactly as $m=F \div a$ is equivalent to $F=m a$ while it is thinking that $M V=P Y$ and $V=P Y \div M$ are different. Hence, quantity theory of money is false.
\end{abstract}

Keywords: money demand, money supply, definition of money, quantity theory of money, monetary policy

\section{Introduction}

\subsection{Failure of Quantity Theory of Money}

I conjecture the truth of quantity theory of money because recent experience about Great Recession fundamentally objects to what quantity theory of money predicts. First, Federal Reserve Bank did not contract money supply so as to trigger subprime loan crisis and Great Recession. Second, inflation rate and growth rate of M2 were low after 2008 although monetary base was expanded to be extraordinarily high by Quantitative Easing. Wen and Arias (2014) accounted for low inflation rate and low growth rate of M2 by the extraordinarily low velocity of monetary base (GDP is divided by monetary base), which declined from 17.2 prior to Great Recession to 4.4 because banks would like to hoard excess reserve rather than lend to business and consumers. Mcleay, Radia and Thomas (2014), published in Bank of England's Quarterly Bulletin, addressed that bank deposit is credit and 97 percent of monetary aggregate is credit. Since borrowing and lending determines money supply, the effectiveness of monetary policy on GDP and inflation rate (i.e., the validity of Fisher's exchange equation) depends on borrowing and lending. It implies that quantity theory of money is false because borrowing and lending is cause while money supply, GDP and inflation rate are effect. This implication coincides with the conclusion of Ting (2012) that price rising rate and income fluctuation are caused by borrowing and lending, not by monetary shock. Ting's conclusion is reinforced by another two facts in addition to Great Recession. First, money demand function has not been stable since Goldfeld (1976) so that Federal Reserve Bank abandoned M1 and M2 to indicate monetary policy. Second, Federal Reserve Bank of New York ceased publishing money supply at 2006 because the relationship between money supply growth rate and the performance of the U.S. economy was broken. It is worth noting that the borrowing and lending in Ting (2012) is related to aggregate investment, aggregate saving and aggregate consumption directly but bank lending may be related to assets (e.g., used car and second hand house) or spillover to foreign countries. Besides, bank lends to mutual fund for financial investment or speculation (e.g., equity, option, derivates, commodity and currency). That is reason why economists cannot criticize Ting's paper due to the reason that bank deposit is credit and bank deposit is the main component of money supply so that the correlation between credit (bank deposit) and GDP is also not stable in time series. Besides, borrowing and lending is flow and credit is stock as investment is flow and capital is stock so that we cannot use credit stock to test Ting's conclusion as we cannot use capital stock to test IS-LM model. Income is flow and flow must be explained by flow as Ting explained fluctuation of income flow by credit flow. 
Since quantity theory of money uses money stock to explain income flow, the theoretical framework of quantity theory of money is false.

Since M2 grew slow after 2008, slow recovery after 2009 was explained by the close correlation between money supply and GDP. It induces me to recall the depression from 1839 to 1843 in U.S., which is also contrary to what quantity theory of money predicts. Rothbard (2002, pp. 101-103) reported that the number of banks fell 23 percent, money supply decreased 34 percent, price level declined 42 percent and investment dropped 23 percent during these five years while real consumption increased 21 percent and real GNP grew 16 percent at the same time. Rothbard's study demonstrated that it is appropriate that central bank contracts money supply during deflationary recession because the relationship between real aggregate income and real money supply is positive. It means that $M V=P Y$ may be false while $(M \div P) V=Y$ is always true (i.e., quantity theory of money regards real income and real volume of money stock).

In addition to Wen and Arias (2014), Bridges, Rossiter and Thomas (2011) also found that reduction in borrowing by households and business was the key factor to explain the weakness of broad money growth in United Kingdom after 2008 and balance sheet repair was secondary. These two papers lead me to ask a question as below. Between 1839 and 1843, did the decrement in quantity of money cause depression or did the decrement in credit, which is caused by depression and bank crisis, explain the reduction in quantity of money? Friedman and Schwartz (1970, Chapter 7) estimated U.S. money stock before 1867, consisting of specie, banknote and deposit. From 1839 to 1843 , the quantity of specie, outstanding banknote and deposit were (83, 101, 79), (80, 107.3, 64.9), (80, 83.7, 62.4), (90, 58.6, 56.2) and (100, 75.2, 84.6). Since monetary base (specie) did not decrease, money supply declined between 1839 and 1843 because both the volume of banknote and the volume of deposit decreased. Since there was no central bank in U.S. at that time, it is wrong to argue that central bank contracted money supply or central bank did not prevent money supply from contraction between 1839 and 1843 so that depression occurred. Seavoy told us that merchants who received loans were given a stack of banknotes and merchant spent banknotes when they purchased (Note 1). As demand deposit is created by bank lending, banknotes were created by bank lending. From 1840 to 1842, the amount of banknotes declined almost 50 percent while specie (i.e., monetary base) was stable and specie increased around 10 percent in 1842 . The increase in specie in 1843 accompanied with huge increase in banknote. It suggests that money supply dropped because banks contracted lending (i.e., supply of credit declined) and economic agents reduced borrowing (i.e., demand for credit decreased) endogenously like M2 grew slow due to sluggish lending and borrowing while monetary base increased in Great Recession. Thus, depression and decrease in credit activity caused reduction in volume of money from 1839 to 1843, which is consistent with Bridges, Rossiter and Thomas (2011) and Wen and Arias (2014) suggested. Monetarists put cart before horse.

Wallis (2001) argued that bank crisis and defaults of nine state government bonds were more important than the decrease in capital inflow from England to affect both U.S. economy and U.S. money supply between 1839 and 1843. People borrowed from state bank to buy land. Then, people used the land they bought to be collateral so that people could borrow from bank and buy land from government repetitively. Land speculation and credit boom drove land price to rise tremendously. When land price collapsed, people abandoned land. Thus, bank loan became default and banks were bankrupt. When a bank is bankrupt, deposit and banknote on this bank's balance sheet is cancelled out from money supply automatically. Thus, bankruptcy of state bank reduced money supply from 1839 to 1843 in addition to contraction of bank loan.

State governments in south issued state bond to invest state banks instead of cash investment. Since bankers did not find investors to invest state bond, state governments did not receive money from bankers. But bankers used those unsold state bonds to be collateral and borrowed from foreign countries because those unsold state government bonds were on bankers' hand. Thus, state governments in south refused to pay interest for those unsold state bond so that state bond defaulted. State governments in west issued state bond to build rail road and canal. Since transportation program did not yield enough fee revenue to pay interest and state government in the west did not raise property tax to back up state bond, state bond of west states defaulted, too. Since state bond is the reserve for state banks to issue banknote, default of state bond means bank did not have enough cash to redeem banknote so that the default of state bond caused bank crisis

In summary, bank crisis and the depression between 1839 and 1843 were caused by both state government bond default and collapse in land price according to Wallis (2001) as bank crisis and Great Recession in 2008 was caused by default of repayment for subprime loan and collapse in house price. Since monetary base did not decreased but money supply decreased endogenously due to reduction in borrowing and lending of economic agents, the change in quantity of money stock between 1839 and 1843 was effect, which did not cause depression. It hints that quantity theory of money is false because monetarists put cart before horse. Thus, the 
objective of this paper is to investigate the truth of quantity theory of money.

\subsection{The Truth of Quantity Theory of Money}

McCallum and Nelson (2010, p.4) stated "The equation of exchange is an identity - it might appropriately be thought of as a definition of velocity. Being an identity, the equation of exchange is consistent with any proposition concerning monetary behavior..." Since $V=P Y \div M$ is the definition of income velocity and nobody can disprove the definition of income velocity by logical inference and economic causality, $V=P Y \div$ $M$ is a true equation. Economists automatically accept that both Fisher's exchange equation and Cambridge money demand function are true because both Fisher's exchange equation and Cambridge money demand function are converted from the definition of income velocity arithmetically and arithmetical conversion is a principle in computation that is also independent of economic theory. Although the truth of quantity theory of money is based on the truth of the definition of income velocity, income velocity in $V=P Y \div M$ explains neither nominal aggregate income nor money demand by itself. The explanatory power of quantity theory of money on economic activities is arising from either Fisher's exchange equation or Cambridge money demand function.

Since it is impossible to prove or disprove the truth of Fisher's exchange equation and Cambridge money demand function by economic theory derived from logical inference and causation (e.g., liquidity trap), Ireland (2015) wrote "But as clean and aesthetically pleasing as its microfoundations might be, the alone are not enough to convince us of the quantity theory's usefulness. Instead, the most compelling reasons to believe in the quantity theory are empirical..." But Cagan (1988, p. 124) stated "The old argument that correlation does not imply causation". Gagan's statement means that there is no quantity theory of money but there is close correlation between aggregate income and quantity of money stock because there is no cause and effect organized by logical inference in $V=P Y \div M$. Thus, the close correlation between quantity of money stock and aggregate income (i.e., income velocity) cannot prove the truth of either Fisher's exchange equation or Cambridge money demand function but can compel economists to accept the usefulness of quantity theory of money.

Both price and quantity that we observe are effect while supply and demand are cause. There is no causality relation between observed price (i.e., ex-post price) and observed quantity (i.e., ex-post quantity). For example, we observe not only inflationary recession (e.g., two oil crises in U.S.) versus deflationary recession (e.g., Great Depression) but also inflationary growth versus deflationary growth (e.g., U.S. between 1839 and 1843). If there is causality between inflation rate and nominal aggregate income, the relationship between inflation rate and nominal aggregate income cannot be not only negative but also positive. Thus, Granger and Jeon (2009) were wrong to test the Granger's causality between wage and unemployment and concluded that change in wage is cause and unemployment is effect because Granger and Jeon should explain the relationship between wage and unemployment by labor supply and labor demand. In other words, Granger's causality test is not able to explain the fact that the slope of Phillips curve are not only positive (e.g., two oil cries in US, Owyang (2015) and Broadberry (2012)) but also negative (e.g., Phillips, 1958). Money demand and money supply are ex-ante to determine quantity of money stock. Thus, quantity of money stock is ex-post. Aggregate income is value of output produced currently. Ting (2012) redefined aggregate income to be $Y^{S}$ (supply of total output) and $Y^{d}$ (demand for total output). Thus, both $Y^{s}$ and $Y^{d}$ are ex-ante while the Keynes' definition of aggregate income $(Y)$ is ex-post. $Y^{s}$ and $Y^{d}$ determine ex-post aggregate income $(Y)$. Thus, there is no causality between quantity of money stock and aggregate income in the sense of ex-post. Since 97 percent of monetary aggregate is credit and Ting (2012) predicted that ex-post aggregate income and ex-post volume of borrowing and lending are pro-cyclical co-movement, there is close correlation between ex-post aggregate income and ex-post quantity of money stock. Thus, Granger's causality test does not work under pro-cyclical co-movement to identify cause and effect between money stock and aggregate income. For example, Sims (1972) found that monetary disturbance causes fluctuation in aggregate income but Thornton and Batten (1985) found that money and aggregate income are bidirectional. In summary, neither economic theory nor empirical study and statistical skill (e.g., correlation and Granger's causality test) can prove or disprove the truth of quantity theory of money.

Since economists methodologically derive both Fisher's exchange equation and Cambridge money demand function from the definition of income velocity, both the truth of Fisher's exchange equation and the truth of Cambridge money demand function not only depend on the truth of $V=P Y \div M$ but also depend on an issue in logical inference, which is so obscure that scientists are accustomed to ignore, especially empirical science like economics. That is, is arithmetic conversion a valid method or an invalid method by which we prove theorems? If the answer for this issue is negative, both Fisher's exchange equation and Cambridge money demand equation have never been proved to be true validly because $V=P Y \div M$ does not tell us that income velocity influences on nominal aggregate income and quantity of money stock by itself. 
Consider $F=m a$, where $F, m$ and $a$ are force, mass and acceleration respectively. As economists arithmetically convert the definition of income velocity into both Fisher's exchange equation and Cambridge money demand function, I convert $F=m a$ into $m=F \div a$. Then, I reach an absurd conclusion that there is no mass if acceleration is equal to zero. For example, you do not have mass when you stand. Since $m=F \div a$ is false, there is no text book of physics referring to $m=F \div a$. Similarly, $M V=P Y$ implies that real aggregate income is zero if there is no money. Thus, barter economy is impossible to exist. But the matter of fact is that barter economy operates in real world and economists cite quantity theory of money every day and everywhere.

Why is arithmetic conversion an invalid method that leads to false theory like $m=F \div a$ ? Kinsler published a paper in 2011 to discuss causality in physics (Note 2). Kinsler reminded us that $F=m a$ is definition expressed by scalar calculation because $m$ and $a$ are not causes to tell us how to generate force from energy. For instance, how many horsepower (force) is generated from car engine and gasoline to accelerate car? Thus, $F=m a$ does not express causation and $F$ is not a factor to determine mass. Force is a scalar in $F=m a$ because force is the magnitude that an object needs to accelerate and $F=m a$ is an equation to measure the magnitude. Since force is not the cause to determine mass and mass is not defined by $m=F \div a, m=F \div a$ is false. In other words, $F=m a$ does not imply $m=F \div a$ because the $F$ in $F=m a$ is not cause but scalar while I convert the definition of force $(F=m a)$ into the mass determination mechanism $(m=F \div a)$ without hesitation because I mistake the scalar $F$ in $F=m a$ for the causality $F$ to determine $m$ in $m=F \div a$. It is equivocation fallacy that one symbol represents more than one concept. I commit equivocation fallacy if I convert $F=m a$ into $m=F \div a$ because $F$ is scalar in $F=m a$ and $F$ becomes cause in $m=F \div a$. In the case of $F=m a$ and $m=F \div a$, I confuse scalar $F$ with causal $F$. Besides, $F=m a$ and $m=F \div a$ are circular reasoning because we must know $m$ before we know $F$ but we need $m$ before we calculate $F$. I conclude that arithmetic conversion is an invalid method to prove theorem. In summary, it is thinking that we are not permitted to derive $m=F \div a$ from $F=m a$ while it is arithmetic computation that I derive $m=F \div a$ from $F=m a$.

Income velocity defined by $V=P Y \div M$ is similar to $F=m a . V$ is scalar calculated by two scalars, ex-post nominal aggregate income $(P Y)$ and ex-post quantity of money $(M)$. Thus, income velocity is not a cause (i.e., exogenous variable) to affect both nominal aggregate income in $M V=P Y$ and quantity of money stock in $M=P Y \div M$ as $F$ is not cause of mass in $m=F \div a$. Why? Since supply and demand determines price and quantity, both supply function and demand function are ex-ante while transaction price and transaction quantity are ex-post. Since Ting (2012) showed that aggregate income is determined by supply of total output $\left(Y^{S}\right)$ and demand for total output $\left(Y^{d}\right)$. Therefore, $P Y$ is ex-post nominal aggregate income and scalar in $V=P Y \div M$. Similarly, money demand and money supply determines ex-post quantity of money stock so that $M$ is scalar in $V=P Y \div M$. Thus, economists mistake the scalar $V$ in $V=P Y \div M$ for the causality $V$ to affect both $P Y$ in $M V=P Y$ and $M$ in $M=P Y \div V$.

It is worth noting that circular reasoning can demonstrate why there is no cause and effect in quantity theory money straightforward. Suppose that central bank uses monetary base and monetary multiplier to forecast nominal aggregate income by $M V=P Y$ and money supply. Then, central bank has to beg $V=P Y \div M$ in order to get the value of income velocity; otherwise central bank cannot forecast nominal aggregate income. But central bank is impossible to know the income velocity in $V=P Y \div M$ because both nominal aggregate income and money supply are not determined yet in $M V=P Y$ in the sense of ex-ante due to the reason that central bank control monetary base only. That is, we need $V$ and $M$ first and then get $P Y$ by $M V=P Y$ next but we need $P Y$ and $M$ before we get $V$ by $V=P Y \div M$.

Logicians tell us that definition, which is defined inside a theory, must be able to be eliminated (criterion of eliminability) because definition is built on primitive notions as well as definition cannot create new theorems (criterion of non-creativity) because definition is not axiom so that definition cannot add anything on a theory (Note 3). Consider a simple simultaneous equations model as below.

$$
\begin{gathered}
a_{11} x_{1}+a_{12} x_{2}+a_{13} x_{3}=y_{1} \\
a_{21} x_{1}+a_{22} x_{2}+a_{23} x_{3}=y_{2} \\
a_{31} x_{1}+a_{32} x_{2}+a_{33} x_{3}=y_{3} \\
z=y_{1} \div y_{2}
\end{gathered}
$$

It is a three equations simultaneous equations model because there are three independent variables $\left(x_{1}, x_{2}\right.$, and $\left.x_{3}\right)$ and three dependent variables $\left(y_{1}, y_{2}\right.$ and $\left.y_{3}\right)$. In other words, there are six primitive notions. Since we get $z$ after we solve $y_{1}, y_{2}$ and $y_{3}, z$ is definition, scalar and ex-post, not variable and primitive notion. Consequently, there is no cause and effect between $z$ and $y_{1} \div y_{2}$ in terms of independent variable and 
dependent variable but there is scalar computation that $y_{1}$ is divided by $y_{2}$. Thus, the concept of $z$ and the concept of $y_{1} \div y_{2}$ are identical so that $z=y_{1} \div y_{2}$ is definition (i.e., we can replace $z$ by $y_{1} \div y_{2}$ wherever $z$ appears according to criterion of eliminability), not a new equation introduced into the model above. Thus, the three equations simultaneous equations model is not transformed into a four equations simultaneous equations model after we introduce the definition of $z$ into the model. That is, definition does not add anything to the model, e.g., $z=y_{1} \div y_{2}$ is not part of the simultaneous equations model. Consequently, it is wrong to declare that we derive two new equations, $y_{1}=z y_{2}$ and $y_{2}=y_{1} \div z$, from $z=y_{1} \div y_{2}$ and these two new equations add new explanatory power to the three equations simultaneous equations model above (i.e., new restriction on $y_{1}$ by $y_{1}=z y_{2}$ and new restriction of $y_{2}$ by $y_{2}=y_{1} \div z$ ) because $\mathrm{z}$ is independent variable, not scalar, in $y_{1}=z y_{2}$ and $y_{2}=z \div y_{1}$. Once again, the three equations simultaneous equations model is thinking while both $y_{1}=z y_{2}$ and $y_{2}=z \div y_{1}$ are arithmetic computation. In summary, definition is redundant in theory from the view point of logical inference for two reasons. Fist, we cannot derive any theorem from definition, e.g., $y_{2}=y_{1} \div z$. Second, we can replace definition by primitive notions which involves definition, e.g., we can replace $z$ by $y_{1} \div y_{2}$. In other words, definition is neither dependent variable nor independent variable.

Suppose that there is a $N$ equations simultaneous equations model in macroeconomics (e.g., IS-LM model) in which there are one equation determines quantity of money stock by money demand and money supply and another equation determines nominal aggregate income by supply of total output and demand for total output. Let $y_{1}$ be $P Y$ and $y_{2}$ be $M$ so that $z$ is the definition of income velocity. Since nominal aggregate income and quantity of money stock are ex-post (dependent variable) determined endogenously, the definition of income velocity is not variable but computation of scalar. If income velocity is a dependent variable, it is wrong to explain a dependent variable by other dependent variables. We have to use not only changes in the independent variables that explain nominal aggregate income (e.g., propensity to consume and marginal efficiency of capital) but also changes in the independent variables that determine quantity of money stock (e.g., borrowing and lending which determines demand deposit) to account for change in income velocity instead of ex-post nominal aggregate income and ex-post quantity of money stock. Although income velocity is determined endogenously, income velocity is scalar instead of dependent variable. Of course, income velocity is not independent variable because independent variables are exogenously determined beyond the model, not determined endogenously. Sometimes, economists assume that income velocity is constant. Assume that income velocity is 3 . Then, we get a new equation $3=y_{1} \div y_{2}$, which assigns a new relationship between $y_{1}$ and $y_{2}$. But $z$ is not an independent variable to assign a new restriction on $y_{1}$ and $y_{2}$ in $z=y_{1} \div y_{2}$ because $z$ results from $y_{1} \div y_{2}$. Since the solution of the three equations simultaneous equation model above does not guarantee $y_{1}=3 y_{2}$, it means that we derive contradictory conclusions from a four equations model instead of three equations model once income velocity is determined exogenously. Since we have to reject a model that contains contradictory conclusions, income velocity is not allowed to be exogenous variable. In summary, the $V$ in $V=P Y \div M$ is scalar, not variable.

In section 2, I explain how logics distinguishes definition form axiom and why logics forbids scientists to derive any theorem from definition, e.g., we cannot infer $m=F \div a$ from $F=m a$.

\subsection{Definition of Money and the Usefulness of Quantity Theory of Money}

Since both Fisher's exchange equation and Cambridge money demand function are false, quantity of money stock and GDP are supposed not to be correlated statistically. But thousands empirical studies confirm that quantity of money stock is closely related to GDP all over the world. The contrary between logical inference and empirical studies is too ridiculous to be tolerated. Thus, the truth of quantity theory of money is not solved completely and soundly if I do not take care of the conflict between logical inference and empirical evidences. It leads me to investigate the definition of money in section 3 for two reasons. First, the concept of GDP and the concept of price index are well defined so that the numeric value of GDP and the numeric value of price index are reliable. Second, there are different definitions of money (e.g., M1, M2 and M3) and empirical evidences, which support quantity theory of money, depend on the definition of money selected by economists. Thus, the definition of money is the only source to create the contrary between logical inference and empirical study.

Friedman (1987, p. 4) wrote "the persistent dispute about whether term money should include only currency or deposit as well." For example, there was the dispute between currency school and banking school in nineteenth century. Friedman and Schwartz ( 1970, p. 105) addressed "Just as earlier writers regarded bank notes as claims to money rather than money itself, and argued that debts could not be discharged finally with bank notes but only 
with the specie that could be obtained for the bank notes, so many current writers argue that time deposit or saving and loan shares or other assets expressed in nominal terms can be used to discharge debt only by being first converted into currency or demand deposit, and hence cannot themselves be regarded as money." Obviously, Friedman knew that medium of exchange is an indispensable feature of money essentially and Friedman knew that his definition of money includes both medium of exchange and non medium of exchange (e.g., time deposit). Is Friedman self-contradictory? Economists should understand that essential features are indispensable when we define an entity because essential features distinguish the defined entity from other entities. For example, the most stable relation between a class of assets and nominal aggregate income (i.e., the most stable income velocity) is the essential feature that Friedman and Schwartz necessarily needed to beg when they recommended M2, which contains time deposit. Otherwise, we do not know why and what "a particular class of asset" Friedman and Schwartz should select.

The main component in Friedman's definition of money is bank deposit. Mcleay, Radia and Thomas (2014, p. 3) wrote "Bank deposits are simply a record of how much the bank itself owes its customers. So they are a liability of the bank, not an asset that could be lent out." That bank deposit is debt (i.e., banks borrow from depositors) coincides with the fact that banks pay interest for deposit and Friedman (1987) affirmed that interest rate is the price of borrowing and lending. According to Mcleay, Radia and Thomas (2014), bank lends out currency, which is medium of exchange, and bank does not lend out demand deposit because demand deposit is not medium of exchange (money). If economists agree that medium of exchange, which discharges payment obligation, is an indispensible feature of money because medium of exchange distinguishes monetary economy from barter economy, then economists should reject the definition of money that contains non medium of exchange (e.g., bank deposit). Otherwise, economists are self-contradictory. But economists are self-contradictory actually because economists know that bank deposit cannot discharge payment obligation and bank does not lend out demand deposit so that bank deposit is not money definitely while the main component of the quantity of money stock, which economists used to study quantity theory of money empirically and central banks count on to forecast business cycle and practice stabilization policy, is bank deposit.

Economists neither acknowledge nor admit that they are self-contradictory about the definition of money because Friedman's positive methodology misled economists to tolerate logical error in economics. Friedman (1953) argued that unrealistic assumption or false premise do not matter while useful conclusion and useful forecasting do matter. If Friedman's positive methodology is correct, we should accept the theory that sun rises from east and sun sets in west because sun rotates around earth from east to west. Although it is useful that we derive true conclusions (e.g., sun rises from east and sets in west) from false premises (e.g., sun rotates around earth from east to west), we still construct false theory and false theory should be rejected by scientists. Since it is a popular idea that definition is metaphysical, it leads economists to believe that it is an endless debate about what money is so that it is useless for economists to understand business cycle by disputing what money is. Usefulness is the reason why economists would like to forecast business cycle by quantity of money stock statistically with logical error rather than investigate the true definition of money and then not only develop the true business cycle theory but also reject the false business cycle theory (e.g., quantity theory of money).

Economists did not recognize that broad money and quantity theory of money are inconsistent logically due to circular definition. Since we shall derive contradictory conclusions from a theory if we violate rules of definition in logical inference, we cannot use broad money to support quantity theory of money statistically. In quantity theory of money, Friedman's empirical approach to define money is a false premise as the case that sun rotates earth from east to west. Why? Since money is a primitive notion to construct quantity theory of money and primitive notions are prior to both axioms and definitions methodologically, essential features that we select to define money are prohibited from being related to both Fisher's exchange equation and Cambridge money demand function. Otherwise, the definition of money is circular definition because the definition of income velocity depends on money while the definition of money depends on income velocity, e.g., Friedman's empirical approach to define money. I conclude that broad money based on both Friedman's positive methodology and Friedman's empirical approach to define money are inconsistent with quantity theory of money logically due to circular definition.

Besides circular definition, Mason (1976) argued that Friedman and Schwartz committed circular reasoning fallacy because Friedman and Schwartz statistically tested the correlation between a class of assets and GDP (i.e., income velocity) first in order to select components included in the class of assets they named "money" and then Friedman and Schwartz statistically tested quantity theory of money by the class of asset which they picked next. Thus, the procedure designed by Friedman and Schwartz to empirically study quantity theory of money is circular so that monetarists never fail to show us that quantity theory of money works universally. Economists 
pay no attention to Mason's critique because Friedman's positive methodology misleads monetarists to ignore any logical error they make.

Since the quantity of currency is too little to disturb economy so hard that monetarists need "broad money" to build up statistical evidences which support quantity theory of money (e.g., M1, M2 and M3), the definition of money and the truth of quantity theory of money are interrelated to be one issue instead of two independent issues as the compelling that Ireland (2015) addressed. Since I disprove quantity theory of money logically in section 2, monetarists must argue with me about the logical structure on which quantity theory of money is built because monetarists cannot defend the truth of logical structure on which quantity theory of money is built by the close correlation between quantity of money stock and aggregate income statistically. Thus, I force monetarists to squarely face the problem that empirical studies, which are based on empirical approach to define money (e.g., broad money), create the inconsistency between logical inference and observations in real world while the inconsistency between logical inference and empirical study is not allowed to exist in science. If I do not disprove quantity theory logically before I discuss the definition of money, monetarists will apply Friedman's positive methodology (i.e., usefulness) to defend empirical approach to define money and then the validity of their empirical studies. Consequently, the discussion of what money is in section 3 will be worthless because it will be trapped into the endless dispute about what money is by Friedman's positive methodology. I will show in section 3 that broad money leads to false conclusion (e.g., money exists in barter economy) so that economists must use medium of exchange and store of value to define money. I will demonstrate that both private banknote and bank deposit (both demand deposit and time deposit) are not money because private banknote and bank deposit are not medium of exchange to discharge payment obligation. Thus, there is no conflict between logical inference and empirical evidence about quantity theory of money in this paper because there is no correlation between currency (i.e., medium of exchange) and aggregate income and the volume of currency is too little to disturb aggregate income.

\subsection{Conclusion}

Since both quantity theory of money and the empirical approach to define money are false, there is no monetary policy but there is credit policy because 97 percent of monetary aggregate is credit. I discuss stabilization policy briefly in section 4 .

\section{Income Velocity: Definition versus Causation}

Equation is not necessary to regard cause and effect. For example, $X^{2}+Y^{2}=Z^{2}$ is an equation that can represent the right angled triangle. But this equation neither means that right angled triangle is cause and $X^{2}+Y^{2}=Z^{2}$ is effect and vice versa nor implies that $Z$ is the effect caused by $X$ and $Y$. Arithmetic conversion (e.g., $Z^{2}-Y^{2}=X^{2}$ ) does not add anything to $X^{2}+Y^{2}=Z^{2}$. Theory expresses the relation between cause and effect verbally and then we translate verbal theory into equations mathematically. Mathematics cannot create cause and effect (i.e., theory) by itself. Consider a case that your teacher of physics asks you a question as below. When you use a motor, which generates 1 horse power, to raises an object from ground to 1 meter high in a second, what is the mass of this object? One horse power means the forces which raises a 75 kilograms object up one meter high in a second, (one horse power $(F)=75$ Kilograms $(m) \times$ one $\frac{\text { meter }}{\text { second }}(a)$ ). We derive the answer that the mass of this object is 75 kilograms from $F=m a$, not from $m=F \div a$, because the mass of this object is also 75 kilograms when this object lies on ground statically. $F, m$ and $a$ are three scalars and force is equal to mass multiply acceleration. Thus, $m=F \div a$ cannot handle the case that acceleration is zero because there is no cause and effect in $F=m a$. In short, arithmetic conversion is not allowed to create or prove a new causal relation that does not exist in a theory. For instance, $m=F \div a$ creates the new causal relation that mass depends on both force and acceleration while $F=m a$ does not tell us that mass depends on force and acceleration.

Income velocity is the corner stone of quantity theory of money for two reasons. First, both Fisher's exchange equation and Cambridge money demand equation are converted from the definition of income velocity arithmetically so that economists believe the truth of quantity theory of money is based on $V=P Y \div M$, which is self-evident. Second, $V=P Y \div M$ does not regard cause and effect as $Z^{2}=X^{2}+Y^{2}$ but income velocity becomes independent variable (i.e., cause) to not only affect aggregate income in Fisher's exchange equation but also influence money demand in Cambridge money demand function. In other words, income velocity creates 
explanatory power of quantity theory of money on economic activities instead of money when income velocity becomes independent variable (cause). Motion is a helpful example to understand why income velocity is neither independent variable nor dependent variable in economic theory (i.e., there is no cause and effect in $V=P Y \div$ $M$ ) but a scalar calculated endogenously as the example of simultaneous equations model in section 1. I replace nominal money stock by time $(T)$ and substitute distance $(D)$ for nominal aggregate income. Then, I get three new equations, $V=D \div T, D=V \times T$ and $T=D \div V$. Since neither distance nor time generates force from energy to accelerate an entity, $V=D \div T$ does not represent the cause of velocity (i.e., neither distance nor time explains velocity). Suppose that we want to know driving speed. We can measure time by clock. Then we measure distance by ruler or count distance by time and the number that wheel turns per second. Like $F=m a$, $V=D \div T$ represents nothing but a method to measure the magnitude of motion (velocity) by scalar calculation instead of the method to measure the magnitude of motion (velocity) by cause and effect.

If we want to derive instant driving speed and average driving speed from energy (cause and effect), the deriving process is long and complicate even under ideal circumstance. First, we calculate chemical energy produced by internal combustion engine from gasoline. Second, we transform chemical energy into kinetic energy because kinetic energy is less than chemical energy due to heat and friction. Third, we derive acceleration from kinetic energy because kinetic energy is in terms of meter/(seconds) ${ }^{2}$. Fourth, instant driving speed is equals to acceleration plus initial speed. Let $f(E, s, t)$ be the function of instant speed where $E$ is kinetic energy, $s$ is initial speed and $t$ is time. By $\int_{0}^{t} f(E, s, t) d t$, we get distance. Finally, average driving speed in the sense of ex-post is equal to distance divided by time. Since we are able to calculate velocity by different methods and get the same result, we would like to apply a relatively simple method (e.g., $V=D \div T$ ) to calculate average velocity rather than insist that average velocity should be calculated from cause and effect.

Although we get the same numerical value of average velocity by different approaches, the causal relation between energy and velocity is true approach to explain changes in velocity, not time and distance. Suppose that you live in Los angles and you decide to visit a friend who lives 100 mile away from your home. When you arrive after two hours driving, your average driving speed is 50 miles per hour. Like transaction, time and distance are ex-post in this case of average velocity calculation. On the way to visit your friend, your actually instant driving speed has been up and down depending on traffic situation and force generated from gasoline combusted in car engine. Time and distance cannot explain in the sense of ex-ante why instant speed changes continuously on the way to visit your friend. Consider another case. If you plan to spend 20 minutes for driving, $V=D \div T$ tells you that the average driving speed is 300 miles per hour. But this result makes no sense because the regular car engine under contemporary technology cannot generate enough force to accelerate your car up to 300 miles per hour and traffic jam in Los Angles does not give you enough space to drive 300 miles per hours without car accident. This example implies that we cannot use $V=D \div T$ to forecast what will happen in real world. These two examples above highlight two facts. First, the speed you actually drive affects the ex-post traveling time and ex-post traveling distance, which implies that both time and distance do not cause driving speed and the $V$ in $V=D \div T$ is ex-post and scalar, which is different from actual driving speed. Second, we cannot use effect magnitude measurement equation like $V=D \div T$ to predict what will happen because it does not accounts for what happened in real world,

Once we understand that causal equation is different from effect magnitude measurement equation, we are ready to investigate the concept of income velocity in quantity theory of money. Income velocity is verbally defined to be the average turnover rate of money, $P Y \div M$. Money does not turn over by itself automatically. As wheel needs energy to push or pull, money turns over because economic agents spend or lend. On the one hand, both households' propensity to consume and entrepreneurs' animal spirit to invest affect how much economic agents plan to spend, how much amount of money economic agents plan to hold averagely in a certain time interval and how much economic agents plan to borrow or lend. From the other hand, aggregate supply regards expenditure in inputs, household saving in form of lending and business borrowing to finance expenditure. From the view point of finance, financial innovation and technology progress in information industry not only make the value of financial asset originating from borrowing and lending more stable than before but also increase the ability to liquidate financial assets. Consequently, the short term idle cash balance that economic agents, including financial institutions, should hold on hand for payment becomes available for lending. Financial innovations increase credit supply while quantity of money is given. Borrowing and lending is the reason why the monetary economy with credit needs less quantity of money than the monetary economy without credit to practice the same volume of transaction. Thus, the causal equation from which we derived average turnover rate of money 
involves consumption, investment, production, money supply, money demand, asset supply, asset demand, credit supply and credit demand. Since production (i.e., supply of total output), consumption and investment (i.e., demand for total output) determine ex-post nominal aggregate income as well as money demand and money supply determine quantity of money stock, income velocity is computation of ex-post nominal aggregate income and ex-post quantity of money stock as we use ex-post traveling time and ex-post traveling distance to compute average velocity. If monetarists argue that income velocity is an exogenous variable because increase in income velocity drives GDP to expand, monetarists put cart before horse because increase in propensity to consume, upward shifting in marginal efficiency of capital and increase in credit supply due to financial innovations drive GDP to grow faster than before so that increase in income velocity is ex-post (effect), not ex-ante (cause). For example, decrease in velocity of monetary base in Great Recession is effect (i.e., ex-post), which is caused by weak borrowing and lending. Please review the simultaneous equations model in section 1 in which aggregate income and quantity of money stock are dependent variable (i.e., ex-post) while income velocity is neither dependent variable nor independent variable, but scalar. In summary, $V$ is scalar in $V=P Y \div M$ and $V=P Y \div M$ is an effect magnitude measurement equation to represent average turnover rate of money in the sense of ex-post so that income velocity cannot explain any economic activity. Consequently, quantity theory of money is false because both Fisher's exchange equation and Cambridge money demand function are built on a wrong idea that income velocity is an independent variable, which is determined exogenously, to influence on economic activity.

Monetarists may argue that that income velocity is ex-ante and exogenous in Cambridge money demand function because income velocity influences on money demand. If Cambridge money demand function regards money demand and arithmetic conversion is valid, then the definition of income velocity and Fisher's exchange equation must refer to money demand. Otherwise, we cannot practice arithmetical conversion. Since Ting (2012) defined ex-ante aggregate income to be $Y^{s}$ (i.e., supply of total output) and $Y^{d}$ (I.e., demand for total output), what do $V=P Y^{d} \div M^{d}$ and $V=P Y^{s} \div M^{d}$ mean? If $Y^{s} \div M^{d} \neq Y^{d} \div M^{d}$, what will happen? Do $Y^{d}$ and $Y^{s}$ affect money demand differently? What is the difference between $Y^{s} \div M^{d}$ and $Y^{s} \div M^{s}$ ? Is it false that exogenous variable (e.g., income velocity in $M^{d}=P Y \div V$ ) is defined by endogenous variable (e.g., income velocity is defined by endogenous variable $M^{d}$ in $V=P Y \div M^{d}$ ) in the same model?

Alternatively, both equivocation fallacy and circular reasoning are also able to show that income velocity is neither ex-ante nor exogenous (cause) but ex-post and scalar (effect). It is equivocation fallacy in quantity theory of money that economists use one symbol $M$ to represent three different ideas. $M$ means ex-post quantity of money stock in $V=P Y \div M$, money supply in $M V=P Y$ and money demand in $M=P Y \div V . V=P Y \div M$, $M V=P Y$ and $M=P Y \div V$ are interchangeable because economists were fooled by arithmetic conversion (i.e., misinterpret an effect magnitude measurement equation to be a causal equation) and equivocation fallacy.

Since economists pick one factor from nominal aggregate income, income velocity and money stock arbitrarily and account for the picked factor by the rest two factors, the logical structure of quantity theory of money is circular reasoning. Monetarists may argue that cause and effect can be reversed circularly when there is feedback and all factors must be determined simultaneously so that circular reasoning is necessary. This argument is not true. Once we introduce an ex-post quantity into an economic theory as cause to explain economic activities, we destroy this economic theory due to circular reasoning. For example, the ex-post definition of aggregate income $(Y=C+I)$ and ex-post consumption function $(C=b Y)$ lead to feedback because $C=b Y$ feedbacks on $Y=C+I$ and then $Y=C+I$ feedbacks on $C=b Y$ circularly. Ting (2012) showed that the $Y^{s}=C^{s}+I^{s}$, $Y^{d}=C^{d}+I^{d}$ and $C^{d}=b Y^{s}$ so that $Y^{d}$ does not feedback on $C^{d}$ although aggregate income and aggregate consumption are interdependent. $C=b Y$ is econometric model to test $C^{d}=b Y^{s}$. Thus, we cannot use ex-post econometric model to develop economic theory because Boumans (2012) criticize the loss of cause and effect in econometrics.

The logical relation between income velocity and interest rate is another case of circular reasoning in quantity theory of money. Friedman (1956) used interest rate, inflation rate, assets selection and aggregate income to determine money demand. Friedman and Schwartz (1982, p. 624) wrote "In consequence, an analysis of velocity is equivalent to an analysis of the demand for money in "real" terms." Since money demand is influenced by interest rate and nominal aggregate income endogenously, income velocity should be determined at least by ex-ante interest rate and ex-ante aggregate nominal income endogenously. Thus, it is circular reasoning that monetarists understand that income velocity depends on interest rate as money demand does but interest rate is determined by money demand and money supply in macroeconomics while income velocity influences on money demand.

Since interest rate is another variable to determine money demand in addition to aggregate income, the relation 
between the ex-post quantity of money stock and the ex-post nominal aggregate income and the relation between the ex-post quantity of money and the ex-post interest rate are many to one mapping instead of one on one mapping. Thus, both the correlation between quantity of money stock and ex-post nominal aggregate income (income velocity) and the correlation between quantity of money stock and ex-post interest rate are random statistically. Empirically, Teles and Zhou (2005) reported that the correlation between interest rate and money demand is positive from 1995 to 2003 while the negative correlation existed in the long run money demand function. If we modify the definition of money (e.g., NewM1 by Lucas and Pablo Nicolini (2015) and monetary divisia by Barnett (1980)) or replace three month Treasury Bill interest rate by average short term market interest rate (e.g., Ball, 2002) to get a new and stable money demand function today, this new and stable money demand function will fail in the future. For example, Higgins and Faust (1981) showed that income velocity of M2 became unstable after Federal Reserve Bank substituted M2 for M1 because income velocity of M1 had been unstable while income velocity of M2 was stable. The variable correlation between nominal aggregate income and quantity of money stock (i.e., unstable income velocity) alludes that both Fisher's exchange equation and Cambridge money demand function are false because the correlation between cause and effect is always stable.

Arguments above would be critique on quantity theory of money rather than the formal disproof of quantity theory of money logically because $V=P Y \div M$ seems to be axiom instead of definition in quantity of money so that economists infer $M V=P Y$ and $M=P Y \div V$ from $V=P Y \div M$. Logicians provide formal method to distinguish definition from axiom. When we construct a theory, we introduce primitive notions first and then we use primitive notions to express axioms and definition next. That is the reason why people confuse axiom with definition frequently. We derive theorems from axiom, not from definition. In other words, axiom regards cause and effect but definition does not. $F=m a$ is not axiom but definition because there is no cause and effect in this formula. Since definition is composed of primitive notions only, definition can be replaced by primitive notions, e.g., $V$ can be replaced by $P Y \div M$. It is criterion of eliminability that all definitions in a theory can be eliminated completely. The objective of criterion of eliminability is to prevent new primitive notions from being introduced into the theory through definition because new primitive notions cannot be eliminated by old primitive notions and new primitive notions create new theory. Since we can substitute $P Y \div M$ for $V$, $M=P Y \div V$ is replaced by $M=P Y \div(P Y \div M)=M$. Similarly, Fisher's exchange equation is equivalent to $P Y=M \times(P Y \div M)=P Y$. Thus, income velocity does not add anything to monetary economics because both Fisher's exchange equation and Cambridge money demand function lose their explanatory power once $V$ is replaced by $P Y \div M$. In other words, both $M V=P Y$ and $M=P Y \div V$ do not exist because income velocity is definition, not a new primitive notion (i.e., income velocity is a new exogenous variable, which cannot be replaced by $P Y \div M)$. In summary, criterion of eliminability proves that $V=P Y \div M$ is not axiom but definition because we can eliminate income velocity in both Fisher's exchange equation and Cambridge money demand function.

Definition is redundant in a theory from the view point of eliminability so that the theory does not change after definition is introduced into theory (i.e., we are not allowed to derive new theorems from definition because, by doing so, theory does not keep intact any more after we introduce definition into theory). It is criterion of non-creativity: if we cannot prove a theorem before we introduce definition into the theory, we are not allowed to derive this theorem from definition. For example, we are not allowed to infer $m=F \div a$ from $F=m a$ because we do not prove $m=F \div a$ before we introduce $F=m a$ into theory of motion. Money and aggregate income are primitive notion to define income velocity. The symbol $V$ in $V=P Y \div M$ does not add any explanatory power to monetary economics because $V=P Y \div M$ does not say that income velocity influences on both aggregate income and money demand. Illogically, income velocity becomes new primitive notion (i.e., new exogenous variable) to explain economic activity in $M V=P Y$ and $M=P Y \div V$ because economists mistake definition for new primitive notion (i.e., economists commit equivocation fallacy). Thus, we are not permitted to prove $M V=P Y$ and $M=P Y \div V$ by arithmetical conversion after we introduce $V=P Y \div M$ into monetary economics as I was wrong to derive $m=F \div a$ from $F=m a$.

In summary, Criterion of non-creativity and criterion of eliminability disprove both Fisher's exchange equation and Cambridge money demand function formally and logically. The objective of a theory is to express cause and effect by logical inference. Since definition describes the essence of an entity by primitive notions, theory keeps intact after a new definition is introduced into theory, e.g., the example of simultaneous equations model with definition, $z=y_{1} \div y_{2}$, in section 1. Criterion of eliminability assures that $V=P Y \div M$ is a definition because we can eliminate $V$ in both $M V=P Y$ and $M=P Y \div V$ so that income velocity is not capable to explain any economic activity. Criterion of eliminability prevents income velocity from becoming a new primitive notion introduced into monetary economics through the formula $V=P Y \div M$ (i.e., criterion of eliminability prevents 
income velocity from being a new exogenous variable (i.e., new primitive notion) to influence on nominal aggregate income and money demand). It coincides with my argument above that $V=P Y \div M$ is effect magnitude measurement equation in which income velocity is not cause to disturb nominal aggregate income and money demand but the ex-post magnitude of effect (i.e., scalar) calculated by ex-post aggregate income and ex-post quantity of money. Hence, economists committed equivocation fallacy once more because $V$ is one symbol representing not only scalar in $V=P Y \div M$ but also exogenous variable (cause) in $M V=P Y$ and $M=P Y \div V$. When economists convert $V=P Y \div M$ into either $M V=P Y$ or $M=P Y \div V$, economists violates criterion of non-creativity because both $M=P Y \div V$ and $M V=P Y$ are derived from the definition of income velocity $(V=P Y \div M)$ while Fisher's exchange equation and Cambridge money demand function are not proved before $V=P Y \div M$ is introduced into monetary economics.

\section{Definition of Money: Bank Deposit and Private Banknote Are Not Money}

The definition of money should tell us how to distinguish money from other entities by essential features as we define species by genus because genus is the essential feature to distinguish one species from another species. Otherwise, we do not know what money is. If we do not know what money is, how can we calculate quantity of money stock in order to test quantity theory of money empirically? Traditionally, economists defined money as medium of exchange because medium of exchange does not exist in barter economy. Medium of exchange does not introduce any theorem into economics but exchange is a primitive notion from which economists derive theorems (e.g., trade is better than non-trade in pure theory of international trade). The idea that medium of exchange does not create economic theory coincides with the conclusion in section 2 that quantity theory of money is false. Instead of medium of exchange, monetarists advocated empirical approach based on statistics to define what money is. Johnson (1962) addressed the purpose of empirical approach to define money clearly in section II C. Johnson wrote "They concerned the related empirical questions of the definition of an appropriated magnitude, and the specification of the variables on which the demand for the selected magnitude depends, questions that pose little difficulty when money is defined as the medium of exchange and its velocity is assumed to be determined by institution factors. These questions lead into the fundamental question of the importance of the quantity of money in monetary theory and monetary policy, since, unless the demand for money - defined to correspond to some quantity the central bank can influence - can be shown to be a stable function of a few key variables, the quantity of money must be a subordinate and not a strategic element in both the explanation and the control of economic activity". Since money had existed before central bank appeared, government can practice monetary policy (e.g., Cipolla (1983) investigated monetary policy of Florence in fourteenth century) and economists can establish monetary theory, especially quantity theory of money, without central bank. For what reasons are we necessary to replace medium of exchange by some quantity that central bank can influence? Gold is money but central bank cannot influence the quantity of gold mined underground or imported from New Continent in sixteenth century. Does Johnson conclude that gold is not money? For what reasons is quantity of money a strategic element to explain and control economic activity? Obviously, Johnson's assertions counted on the truth of quantity theory money. Since I showed that quantity theory of money is false in section 2, this paper is absolute contrary to empirical approach to define money.

Further, Johnson wrote "who carry recognition of the similarity between money and other realizable assets or means of financing purchase to the point of rejecting money in favor of some much broader concept, measurable or unmeasurable. A measurable concept is exemplified by the long-established Federal Reserve Board theory that what matters is the total amount of credit outstanding, the quantity of money exercising an influence only because bank credit is a component of total credit... An unmeasurable concept is exemplified by the Radcliffe Committee's concept of the liquidity of the economy..." Certainly, Johnson's definition of money included bank deposit (i.e., outstanding credit) intentionally because the quantity of currency (i.e., medium of exchange) is too small to disturb aggregate income as quantity theory of money predicts but bank deposit, especially demand deposit, is a strategic element to explain and control aggregate income. In principle, predictions derived from an economic theory should be consistent with data we observed in real world (e.g., Ting (2012) argued that flow of credit (i.e., borrowing and lending) causes business cycle and medium of exchange does not cause business cycle based on the fact that medium of exchange and credit are different). But Johnson manipulated data to fit in predictions made by quantity theory of money (i.e., the empirical approach to define money contains bank credit (demand deposit) intentionally in order to get close correlation between quantity of money stock and aggregate income while credit and money are different).

Friedman and Schwartz (1970, p. 106) argued that the major difficulty with medium of exchange concept of money is that it begs the question, "what is the essential feature of money?" Instead, Friedman and Schwartz (1970) proposed that "money" should be defined to be either the class of assets which has the best correlation 
with nominal aggregate income implied by Fisher's exchange equation or the class of assets with the most stable income velocity derived from Cambridge money demand equation, e.g., M1 and M2. Ironically, Friedman and Schwartz are inevitable to beg either the most stable income velocity or the best correlation with aggregate income to be the essential feature that distinguishes the class of assets, which Friedman and Schwartz defined to be money, from other assets. Otherwise, Friedman and Schwartz could not tell us what money defined by them is I conclude that essential features are indispensible when economists define what money is.

Certainly, money has evolved from commodity (e.g., shell, tobacco and gold) to symptom (e.g., coin, paper money under gold standard and paper fiat money without commodity reserve). The meaning of money and essential features of money have extended for thousand years. For example, gold is definitely different from paper fiat money based on partial reserve gold standard because government may be default to redeem paper fiat money by gold. When an economist lists an essential feature that gold has but paper fiat money, based on partial reserve gold standard, does not have (e.g., there is no risk of default for gold but there is risk of default for partial reserve gold standard), he cannot convince his colleagues to accept the statement that gold is money but paper fiat money based on partial reserve gold standard is not money. Thus, economists must use common features, which all kinds of money have, to distinguish money from non money, e.g., medium of exchange and store of value. We cannot use non common feature to distinguish money from non money, e.g., risk of default under partial reserve gold standard. Consequently, there is no reason to insist that all kinds of money should be identical. It seems to be reasonable that Friedman and Schwartz extend their idea about money from medium of exchange to a particular class of assets because all kinds of money store of value and all kinds of assets can store value. But the key point is that some assets are not medium of exchange (e.g., house and antique) and Friedman's definition of money consists of medium of exchange and non medium of exchange while medium exchange is one of common (essential) features to distinguish money from non-money in addition to store of value. Thus, Friedman is wrong.

The issue of definition of money is different from the issue of the definition of income velocity from the view point of logical inference. Income velocity is a definition inside quantity theory of money because income velocity is defined by two primitive notions in quantity theory of money, nominal aggregate income and money. Thus, $V=P Y \div M$ is self-evident. Since money is a primitive notion in quantity theory of money, the definition of money must be beyond quantity theory of money. When Friedman and Schwartz define money to be a class of assets that has the most stable income velocity (i.e., the best correlation between a class of assets and aggregate income), Friedman and Schwartz used income velocity to define money. Thus, not only money becomes a definition inside quantity theory of money instead of primitive notion but also the definition of money and the definition of income velocity become circular definitions. That is, the definition of money depends on income velocity while the definition income velocity depends on the quantity of money (i.e., definition of money) and aggregate income. Logical inference bans circular definitions. If we accept the definition of money as a class of assets that has the best correlation with GDP, then we can find a class of asset that has the best correlation with GDP in barter economy, e.g., life stock for nomad. But money does not exist in barter economy. Thus, we derive a false conclusion from the definition of money proposed by Friedman and Schwartz. Since we can derive false conclusions (e.g., the money defined by Friedman and Schwartz exists in barter economy) from the empirical approach to defined money proposed by Friedman and Schwartz, we have to reject the empirical approach to define money proposed by Friedman and Schwartz.

Once we understand that we have to define money by essential features beyond quantity theory of money because money is a primitive notion in quantity theory of money, we can start to investigate the question how to calculate the total amount of money correctly. All economists agree that there are at least two common (essential) features related to all kinds of money. First, money stores value. Second, money is medium of exchange and the function of medium exchange is to discharge payment obligation. All assets can store value. But it is wrong that every asset is money. For example, diamond stores value reasonably well but diamond is not medium of exchange because diamond is difficult to be divided into small quantity for retail transactions and common economic agents cannot identify the quality of diamond accurately. But it is possible that diamond is accepted to be payment by sellers when the amount of a deal is huge. Logically, it is wrong that money must be precious metal from the view point of store of value because debt claim is another way to store value. I conclude that debt claim is a candidate of money like current U.S. dollar. Once a debtor cannot commit his repayment obligation, the claim issued by the debtor is worthless. Thus, the value of a debt depends on debtor's assets and income. In other words, the value of paper fiat money without commodity reserve depends on economy scale, the volume of total government debt and the ability of government to collect enough tax from aggregate income and assets to support its debt when paper fiat money is pure debt claim instead of 100 percent reserve gold standard. That is 
the reason why the paper fiat money of a small country (i.e., small economy scale and small volume of paper fiat money to the volume of international trade relatively) cannot circulate internationally and the probability of currency crisis of a small country is higher than a large country. Since there is no theoretical foundation to prove that gold stores value better than debt (e.g., gold price fluctuated in medieval age, oil crisis and Great Recession), gold standard is not more stable than paper fiat money without commodity reserve.

Logically, if it is money, then it discharges payment obligation. Thus, if an asset cannot discharge payment obligation, then this asset is not money. Besides, it is wrong that the entity is money if an entity discharges payment obligation, e.g., payment is discharged by particular goods in barter exchange. Thus, medium of exchange cannot prove that an entity is money by itself. For example, paper fiat money without reserve is medium of exchange to discharge payment obligation by law but paper fiat money cannot store purchasing power during hyperinflation so that economic agents refuse to accept paper fiat money as payment. Thus, paper fiat money does not perform as money anymore substantially during hyperinflation although paper fiat money is medium of exchange legally. I will use non medium of exchange to explain why bank deposit and private banknote are not money as below.

To discharge payment obligation is an issue of agreement and law, not economics. For example, both the banknote issued by Federal Reserve Bank and the banknote issued by Bank of England are legal tender enforced by law to discharge payment obligation. Since payment obligation may not be committed fully (e.g., defect goods, delay payment and counterfeit in monetary economy), law is introduced into society to determine injury caused by inappropriate payment. Thus, law can tell us that an entity is medium of exchange or not. If an interpretation of the payment obligation discharge made by an economist is different from law, then this economist's interpretation is not a fact. If economists do not use facts to construct an economic theory, this economic theory is false even economists can derive true conclusions from this economic theory.

Since promissory notes (e.g., bill of exchange and banknote) and bank deposit have evolved tremendously since medieval, the meaning of "banknote" and the meaning of "deposit" have changed as time goes by. I investigate what bank deposit is before I discuss what banknote is because banknote originated from bank deposit. Muller (1997, pp. 12-13) talked about the difference between "regular deposit" and "irregular deposit" in Venetian bankrupt law at 1330. "Regular deposit" means bailment. That is, bank provides warehouse and security for you to store your money but you absolutely do not transfer the title of your money to bank. U.S. court also confirmed that safety deposit box is the contract of bailment in Seitz V. Lemay Bank \& Trust, 959 S. W. ID458, 1998. Under bailment, bank is not entitled to own your money so that bank cannot lend your money to bank's customers. Historically, there were "regular deposit bank" that accepted only "regular deposit" with storage fee charge and did not lend depositor's money to their customers, e.g., Bank of Amsterdam (Note 4). The key point of "regular deposit" is that "regular deposit" is not bank's liability and the money, which is "regularly" deposited in bank's vault, is not bank's asset.

Bank (depository) is entitled to own your money and employ your money to lend out when you practice "irregular deposit". That is, you lend your money to bank. There are four evidences to support the argument about "irregular deposit" versus "regular deposit". First, commercial banks pay interest to "irregular deposit" and interest rate is the price of borrowing and lending. Second, banks who pay interest for "irregular deposit" are entitled to own depositors' money to run loan business so that you lose your "irregular deposit" (i.e., debt claim) when banks are bankrupt. Third, bank charges fee for "regular deposit" (e.g., Bank of Amsterdam and safety deposit box) and does not pay interest for "regular deposit". Fourth, you lose nothing if you deposit your money in safety deposit box of a commercial bank while this bank is bankrupt. Thus, deposit is another case of equivocation fallacy because "deposit" is one word to represent two different contracts in kind, contract of bailment and contract of borrowing and lending.

I use Pater Tenebrarum's blog to show that most people confuse "regular deposit" with "irregular deposit" (Note 5). Tenebrarum wrote:

Since John has given his currency to the bank for the purpose of warehousing and facilitating (by check or via electronic transfer), John retains full command over his money. He did not "lend it to the bank" (Although it should be mentioned that Anglo-Saxon legal tradition via case precedent has sadly frequently disagreed with this view.)

After King Charles I seized gold stored in mint by merchants as forced loan in 1640, merchants preferred to storing their gold with London goldsmiths, who possessed private vaults and charged fee for storage service (Note 6). Obviously, warehousing (i.e., regular deposit) does not give depositary the right to use the property stored by depositors. Otherwise, King Charles I was unnecessary to seize because he had the right to utilize gold 
stored in the mint. Islam bans lending so that depositary is prescribed severely to utilize deposited property. Consequently, Islam Banking appeared behind the West for several centuries (Note 7). "Regular deposit" explains why goldsmith in London did not involve lending in the beginning. If bailment is the contract between depositors and bank, bank is prohibited from lending the warehoused money to bank's customers by law as Islam did. For example, Holland banned chargers, who keep money or receive money for merchants, to lend merchants' money to others in Article 37 of the decree of March 21, 1606 (Note 8). Tenebrarum's argument is against both economic history and the common law because he did not distinguish "regular deposit" (i.e., bailment) from "irregular deposit" (i.e., borrowing and lending). In short, Tenebrarum did not explain not only why depositors receive interest from bank if bank does not borrow money from depositors but also why bank employs depositors' money to lend out legally if bank is not entitled to own depositors' money. Besides, Tenebrarum did not explain why John cannot facilitate his money by check when John warehouses his money in safety deposit box and why John does not retain full command over his money when John deposits his money to be time deposit or saving account. The reason is that check is an order to notify bank that the check issuer terminates his lending to bank in terms of checking account, not saving account and time deposit account, and asks bank pay his money to the order of person or institution.

Since regulation Q prohibited banks from paying interest for demand deposit, economists cannot use non-interest bearing demand deposit in U.S. history to be the evidence that demand deposit is "regular deposit". If depositors warehouse their currency in commercial bank and commercial bank is not allowed to employ depositors' money to lend, economists are required to tell us for what good commercial bank does not charge depositors warehouse fee but provides check clearing service free? If deposit means bailment and banks is bankrupt, why don't we find warehoused money from bank's vault and then give warehoused money back to depositors? Economists may argue that bankers steal depositors' money and then lend to someone else as well as stealing is the reason why Federal Deposit Insurance Corporation provides insurance to protect depositors. This argument cannot explain three facts as below. First, a person stores his money in the safety deposit box provided by bank and he will lose nothing without insurance when bank is bankrupt. In other words, why does not bank steal money deposited in safety deposit box? Second, why does government refuse to ban bank from lending depositors' money to bank's customers as Holland did? Third, why is bank bankrupt while bank manager does not steal customers' money?

Consider a case as below. A person has demand deposit in bank A and this person intends to transfer his money from bank A to bank B so that this person writes a check and deposit the check into his checking account in bank B. Then, bank A announces bankruptcy during check negotiating. Since this person's demand deposit on the accounting book of bank A is sufficient to pay his check, why is this person's check bounced? The answer is that demand deposit cannot discharge payment obligation but currency does because demand deposit is a loan contract in terms of currency. Check is means of payment. This person's check notifies bank A that he terminates a certain amount currency lending as well as he asks bank A to transfer the certain amount currency to bank B. Since bank B does not receive currency from bank A due to bankruptcy of bank A, this person's check bounced so that bank B does not borrow from this person in terms of currency. This case coincides with the statement in Mcleay, Radia and Thomas (2014) that deposit is not an asset that bank can lend out. In other words, demand deposit is not able to discharge payment obligation.

Most economists confuse demand deposit with currency (i.e., medium of exchange). Woolsey, who is market monetarism, published an article in his blog at 11/15/2009, entitled "Money and Credit Confused" (Note 9). Woolsey wrote "Money is medium of exchange... But money and credit are not the same thing... While it is possible that new money is lent into existence, raising the quantity of money over a period of time while augmenting the supply of credit..." Since Woolsey assured that money is different from credit, bank lending (i.e., supply of credit) should bring about credit in credit market and bank lending should not bring about money in money market. Is Woolsey self-contradictory? Bank lends medium of exchange (e.g., currency) to borrowers because the loan contract between bank and borrowers is in terms of medium of exchange. While borrowers receive medium of exchange, borrowers "irregularly" deposit medium of exchange, which they borrow from bank, into their checking account immediately. Thus, there are two loan transactions in what economists name "money creation". On the one hand, bank lends currency out (i.e., cash expenditure) and bank loan is the asset acquired by cash expenditure of bank. On the other hand, bank receives currency from bank loan borrowers by "irregular" depositing and "irregular deposit" is bank's liability corresponding to cash receiving. Since bank lending does not create medium of exchange because the amount of cash on bank's balance sheet neither increases nor decreases, there is no medium of exchange creation by bank lending in real world although demand deposit increases. Economists can test my argument that money creation is two loan contracts by bookkeeping and principle of accounting. 
Financial institutions had issued banknote to be either certificate of "irregular deposit" or warehouse receipt of "regular deposit" before banknote became legal tender in U.S. and British. If you were to store a certain amount of silver, gold or coin in a London goldsmith in sixteenth century, you would get a warehouse receipt from the London gold smith. In this case, London goldsmith was similar to "regular deposit bank" as Bank of Amsterdam. During that era, banknote was issued by handwriting with depositor's name (i.e., payee) and the amount of a certain kind of coin or specie stored by payee. There was no printing banknote with fixed denomination. Banknote is means of payment, not payment, whether banknote is certificate of "irregular deposit" or warehouse receipt of "regular deposit" because banknote may be default. Banknote is not bank's liability if banknote is certificate of "irregular deposit". Otherwise, we count bank's liability twice. For example, one person deposits US \$ 100 in his checking account and ask bank to issue a US \$ 100 certificate of deposit (i.e., banknote). In this case, bank receives cash US \$100 as asset but records both US \$100 demand deposit and US \$ 100 banknote as liability. Since banknote becomes legal tender, banknote discharges payment obligation so that banknote is not certificate of deposit under non commodity reserve monetary regime.

When banks lend to borrowers, banks provide banknote to borrowers as means of payment instead of currency and demand deposit. As demand deposit, banknote is bank's liability corresponding to bank loan. Banknote is another case of equivocation fallacy because the word "banknote" represents not only bank's liability (redemption without payee's deposit) but also non bank's liability (warehouse receipt and certificate of "irregular deposit").

When a buyer (payee) transfers his banknote to his suppliers in order to avoid the cost to carry his coin or specie to his suppliers, banknote is the order that asks bank to transfer payee's specie or coin to payee's supplier (Note 10). Under this circumstance, banknote is not medium of exchange to discharge payment obligation but an instrument to facilitate payment (i.e., means of payment) because a business contract is based on the exchange between goods and specie, not the exchange between goods and banknote. In Scotland, commercial banks have issued private banknotes since sixteenth century and these private banknotes have never been enforced to be legal tender by law as banknote issued by Bank of England, which became legal tender at 1797. Law of Scotland can provide evidences to identify that private banknote can discharge buyer's payment obligation or not. George Joseph Bell who was law professor of Scotland in the University Edinburgh wrote in 1845 "The same rule has been applied where a banker's note taken without agreement to receive them as money, and the banker failed next day. The Court held, that if the defendant had agreed to take the notes as payment, and to run the risk of their been paid, that would have been considered as payment whether the notes had or had not afterwards been paid, but without such agreement the giving of such notes is no payment." (Note 11) Bell's statement is clear that buyer's payment obligation is not discharged if banks fail to redeem their private banknotes by currency and seller does not run the risk of bank redemption default. It is the same as the case that bounced check cannot discharge buyer's payment obligation while the buyer has sufficient demand deposit in his checking account and bank is bankruptcy during check negotiating. Thus, private banknote issued by commercial bank is not medium of exchange but means of payment. It is worth noting that readers should pay attention to agreement instead of law. Law does not determine what payment should be. The agreement between buyer and seller determine what payment is. For example, economic agents disagree to accept paper fiat money to be payment but ask real goods to be payment under hyperinflation.

Yang (2007) understood that means of payment and medium of exchange are different. Check is instrument to deliver check writer's medium of exchange (e.g., currency) to check holder's bank account. Check is means of payment, not medium of exchange. Since Yang confused demand deposit with medium of exchange, Yang believed that demand deposit is medium of exchange and bank delivers your demand deposit to check holder's bank account. Although Young knew the difference between means of payment and medium of exchange, Young did not understand the difference between demand deposit and medium of exchange.

Check and bill of exchange also demonstrates that empirical approach to define money is arbitrary. By endorsing, check and bill of exchange circulated in market as banknote circulated. But outstanding check is not defined to be money by monetarists while monetarists argued that traveler check is money. If monetarists accept that private banknote is money, monetarists should agree that both circulated check and circulated bill of exchange are money. Since there is no data to calculate the total amount of outstanding check and outstanding bill of exchange which are endorsed and circulated, monetarists do not know the total amount of money if monetarists accept that circulated check and circulated bill of exchange are money. It explains why monetarists have never discussed circulated check issued by private economic agents and circulated bill of exchange issued by merchants. Besides, monetarists do not tell us that every economic agent can create money if we define demand deposit and private banknote to be money. Suppose that an economic agent takes US $\$ 100$ from his wallet and 
deposits it in his demand deposit account. In this case, he creates US $\$ 100$ without bank lending because the total amount of currency is the same as before but the total amount of demand deposit increases US $\$ 100$. If this economic agent asks bank to certify his deposit by a private banknote, he creates another US $\$ 100$. If quantity theory of money is correct and bank deposit is money, government can cure recession by raising interest rate because economic agents will reduce the volume of money they hoard and deposit it into bank so that the growth of bank deposit will drive aggregate income to grow according to quantity theory of money.

After I demonstrate that neither bank deposit nor private banknote is medium of exchange so that bank deposit and private banknote are not money, economists cannot but agree with me that the quantity of money is too little to disturb aggregate income. Thus, there is no empirical evidence to support quantity theory of money and then there is no conflict between logical inference and empirical studies about quantity theory of money in this paper.

\section{Conclusion}

This paper proves that quantity theory of money is false. Ting (2012) concluded that borrowing and lending cause business cycle. Ting's conclusion implies that quantity theory of money is false. Since borrowing is demand for credit and lending is supply of credit, borrowing and lending is flow, not stock. The long-established Federal Reserve Board theory regards total amount of credit, which is stock. If economists plan to test the relation between business cycle and credit flow empirically, economists cannot use the total amount of credit to test. Moreover, economists have to update components of the aggregate of credit flow because financial innovations may create new instruments by which economic agents get external fund for their investment and consumption. It is reasonable that monetarists attack definition of credit flow by updating components of the aggregate of credit flow as I attacked empirical approach to define money above by updating components of monetary aggregate. Certainly, I allow new type of borrowing and lending (e.g., subprime loan) to be introduced into the aggregate of credit flow as I agree with that economists introduce new medium of exchange (e.g., paper fiat money without commodity reserve) into the definition of money. But empirical approach to define money introduces not only new medium of exchange but also non medium of exchange (e.g., means of payment like traveler check) into the definition of money. That is the difference between my approach to define the aggregate of credit flow and empirical approach to define money.

The confusion between credit and medium of exchange has great impact on stabilization policy. Let's study the case of 1844 Bank Charter Act in England. Banknote issued by Bank of England became legal tender at 1797. When Bank of England created banknote by bank loan, bank of England also created medium of exchange. Since Bank of England had to redeem his bank note by gold when banknote holders requested, bank note issued by Bank of England is means of payment. Like trinity, banknote issued by bank of England is liability, medium of exchange and means of payment. Since bank note was more important than bank deposit to finance business in the first half of nineteenth century and bank note issued by Bank of England was reserve for private banks to issue their own private banknote, Bank of England was effectively to affect the total volume of bank lending by its own reserve rule to control the volume of its own lending (i.e., banknote issuing). Although 1844 Bank Charter Act controlled bank note issued by Bank of England and left private bank lending free, Bank of England was able to control total volume of borrowing and lending so that Bank of England stabilized economy effectively as Ting's credit flow business cycle theory predicts. Besides, interest rate manipulation is capable to affect credit demand and international gold flow. That is reason why 1844 Bank Charter Act was successful to stabilize economy before bank note was replaced by bank deposit to finance business.

Goodhart and Jensen (2015, p. 4) wrote "The 1844 Bank Charter Act subsequently had to be suspended during crisis, and soon ceased to operated as initially intended. To currency School supporters, this was due to a (somewhat accidental) shift from notes to bank deposits as main component of money. To banking school adherents, there was nothing accidental about this shift; if the authorities try to impose constrains on private sector's access to liquidity, it will attempt to innovate it way around that." It was a financial innovation that bankers substituted bank deposit for banknote issuing to be the main instrument to finance business in order to avoid credit control arising from Bank Charter Act through the control of the volume of banknote issued by Bank of England. Thus, the relation between banknote issued by Bank of England and credit supply became weaker and weaker so that Bank of England could not influence economic activity through credit supply by reserve rule on its bank note issuing as effectively as before. Similarly, Federal Reserve Bank returned to interest rate policy and discretion in the second oil crisis because Federal Reserve Bank could not control monetary aggregate effectively. The matter of fact is that Federal Reserve Bank could not control credit aggregate because the main component of monetary aggregate is credit. Goodhart and Jensen (2015) believed that rule versus discretion has been the ongoing confrontation of stabilization policy since the dispute between currency school versus banking school. But I disagree with Goodhart and Jensen because credit flow business cycle theory predicts that 
stabilization policy succeeds if central bank controls the volume of credit flow effectively whether central bank applies rule or discretion. For example, Federal Reserve Bank can control monetary base and interest rate but cannot control monetary multiplier because Federal Reserve Bank cannot control incentive to borrow and lend, e.g., Great Recession.

\section{References}

Ball, L. (2002). Short Run Money Demand. NBER Working Paper No. 9235. https://doi.org/10.3386/w9235

Barnett, W. A. (1980). Economic Monetary Aggregates: An Application of Aggregation and Index Number Theory. Journal of Econometrics, 14, 11-48. https://doi.org/10.1016/0304-4076(80)90070-6

Boumans, M. (2012). The Regrettable Loss of Mathematical Moldingin Econometrics. In H. K. Chao, S. T. Chen, \& R. Millstein (Eds.), Mechanism and Causality in Biology and Economics. Springer Dordrecht Heidelberg New York London.

Bridge, J., Rossiter, N., \& Thomas, R. (2011). Understanding the recent weakness in broad money growth. Quarterly Bulletin Bank of England, 22-36.

Broadberry, S., Campell, B., Klein, A., Overton, M., \& Leeuwen, B. V. (2012). British Business Cycle, 1270-1870. Retrieved from https://www.ise.ac.uk/economicHistory/pdf/broadberry/britishCycle4a.pdf

Cagan, P. (1988). Money-Income Causality - a Critical Review of the Literature Since "A Monetary History”. In M. D. Bordo (Ed.), Money, History and International Finance: Essays in Honor of Schwartz, A. J. (pp. 117-160). University of Chicago Press.

Cipolla, C. (1983). The Monetary Policy of Fourteenth-Century Florence. University of California Press.

Friedman, M. (1953). The Methodology of Positive Economics: Essays in Positive Economics (pp. 3-43). University of Chicago press.

Friedman, M. (1956). The Quantity Theory of Money: A Restatement. In M. Friedman (Ed.), Studies in the Quantity Theory of Money. University of Chicago press.

Friedman, M. (1987). Quantity Theory of Money. In J. Eatwell, M. Milgate, \& P. Newman (Eds.), The New Palgrave: A Dictionary of Economomics (vol, 4, 3-20). New York: Stockton Press. https://doi.org/10.1057/978-1-349-95121-5_1640-1

Friedman, M., \& Schwartz, A. J. (1970). Monetary Statistics of the United States: Estimates, Sources, Methods. Retrieved from http://www.nber.org/books/frie1979-1. Chapter 2, Prior Usage, Retrieved from http://www.nber.org/chapters/c5280.pdf. Chapter 7, Estimate for the Period Before 1867, Retrieved from http://www.nber/org/chapters/c5286

Friedman, M., \& Schwartz, A. J. (1982). The role of Money (pp. 621-632). Retrieved from http://www.nber/chapters/c11412

Goldfeld, S. (1976). The Case of Missing Money. Brookings paper on Economic Activity, 683-739. https://doi.org/10.2307/2534372

Goodhart, C., \& Jensen, M. (2015). Currency School versus Bank School: An Ongoing Confrontation. Economic Thought, 20-31.

Granger, C. W. J., \& Jeon, Y. (2009). The evolution of the Phillips curve: A modern time series viewpoint. Economica, 78, 51-66. https://doi.org/10.1111/j.1468-0335.2009.00839.x

Higgins, B., \& Faust, J. (1981). Velocity Behavior of the New Monetary Aggregate. Economic Review, 3-17.

Ireland, P. N. (2015). Money Demand and the Quantity Theory. Discussant's comments: On the Stability of Money Demand, presented by Robert Lucas and Joan Pcblo Nicolini at the November 2014 Carnegie-Rochester-NYU Conference on public policy. Retrieved from http://irelandp.com/papers/crcsmdqt.pdf

Johnson, H. G. (1962). Monetary Theory and Policy. American Economic Review, 52, 335-384.

Lucas, R. E., \& Nicolini, J. P. (2015). On the Stability of Money Demand. Working Paper No. 718, Federal Reserve Bank Minneapolis. https://doi.org/10.1016/j.jmoneco.2015.03.005

Mason, W. E. (1976). The Empirical Definition of Money: A Critique. Economic Inquiry, 14, 525-538. https://doi.org/10.1111/j.1465-7295.1976.tb00440.x

McCallum, B. T., \& Nelson, E. (2010). Money and Inflation: Some Critical Issues. Finance and Economics Discussion Series, No. 2010-57, Federal Reserve Board, Washington DC. https://doi.org/10.2139/ssrn.1960052 
Mcleay, M., Radia, A., \& Thomas, R. (2014, Q1). Money Creation in the Modern Economy. Quarterly Bulletin, Bank of England,.

Muller, R. C. (1997). The Venetian Money Market: Banks, Panics, and the Public Debt; 1200-1500. Johns Hopkins University Press.

Owyang, M. (Sept. 21, 2015). Has the Phillips Curve Relationship Broken Down. Federal Reserve Bank St. Louis.

Phillips, A. W. (1958). The Relation between Unemployment and the Rate of Change of Money Wage Rates in United kingdom, 1861-1957. Economica, 25, 283-299.

Rothbard, M. N. (2002). History of Money and Banking in the United States: The Colonial Era to World War II.

Sims, C. A. (1972). Money, Income, and Causality. American Economic Review, 62, 540-552.

Teles, P., \& Zhou, R. (2005). A Stable Money Demand: Looking for the Right Monetary Aggregate. Economic Perspective, 29, 50-63.

Thornton, D. L., \& Batten, D. S. (1985). Lag-Length Selection and Tests of Granger Causality between Money and Income. Journal of Money, Credit and Banking, 17, 164-178. https://doi.org/10.2307/1992331

Ting, C. C. (2012). The True Cause of Business Cycle. European Journal of Business and Economics, 4, 47-51.

Wallis, J. J. (2001). What Caused Crisis of 1839. NBER Historical Working Paper No. 133. https://doi.org/10.3386/h0133

Wen, Y., \& Arias, M. A. (Septemper 1, 2014). What Does Money Velocity Tell Us about Low Inflation in the U.S.? Federal Reserve Bank of St. Louis.

Yang, B. Z. (2007). What is (not) money? Medium of exchange [not equal to] means of payment. The American Economist, 51, 101-104. https://doi.org/10.1177/056943450705100213

\section{Notes}

Note 1. Seavoy, R. E. (2013). An Economic History of the United States: From 1607 to the Present (p. 97). Routledge, Tayor and Francis Group.

Note 2. Kinsler, Paul. (2011). How to causal: time, spacetime and spectra. European Journal Physics, 32, $1687-1700$.

Note 3. Suppes showed how to make definition correctly in a theory in Chapter 8 , which is the foundation of section 2 and 3. Suppes, P. (1957). Introduction of Logic, Van Nostrand Reinhold Company.

Note 4. Bank of Amsterdam, Wikipedia.

Note 5. http://www.acting-man-com. (December 18, 2010). Money and Credit - There Is a Difference.

Note 6. History of Money, Wiki Encyclopedia.

Note 7. Udovitch, A. (1975). Reflection on the Institutions of Credit and Banking in the Medieval Near East. Studia Islamica, 41, 5-21.

Note 8. Robert de Fremery. An Application of Natural Laws to the Problem of Money - The Disastrous Economic and Political Consequences of our Unsound Monetary System - A Suggested Remedy. Chapter III: Origin of Banking. http://www.cooperaative-individualism.orgfremeny

Note 9. http://www.monetaryfreedom-billwoolsey-blogspot.com

Note 10. Quinn, S. F., \& Roberds, W. (2003). Are On-Line Currencies Virtual Banknotes? Economic Review, Federal Reserve Bank Atlanta, second quarter, pp. 1-15.

Note 11. Bell, George Joseph. (1845). Inquiries into the contract of sales on goods and merchandises. http://Books.google.com.hk.

\section{Copyrights}

Copyright for this article is retained by the author(s), with first publication rights granted to the journal.

This is an open-access article distributed under the terms and conditions of the Creative Commons Attribution license (http://creativecommons.org/licenses/by/4.0/). 